\title{
Comentário a \\ “EM BUSCA DO(s) DEUS(ES) AUSENTE(S): O MODO DE VIDA populista em Laclau e em Chaui”: Polêmico populismo
}

Homero Santiago ${ }^{1}$

Referência do artigo comentado: MAESO, B. E. A. Em busca do(s) deus(es) ausente(s): o modo de vida populista em Laclau e em Chaui. Trans/form/açáo: revista de filosofia da Unesp, v. 44, n. 4, p.49-72, 2021.

Não é tarefa fácil desvendar o sentido do conceito de populismo. Seu amplo emprego no debate político parece inseparável da descida à vala da opiniáo e da polêmica; o termo costuma prestar-se prioritariamente à ofensa nua e crua: "populista" é sempre o outro, aquele que não pensa como eu penso e não toma as decisôes que acredito corretas; destarte, a espessura da palavra resulta similar à de "ateu": é simplesmente aquele que não acredita no nosso deus - pronto e acabou. Tratar-se-ia de mera deformaçáo de um uso inicialmente rigoroso? Aparentemente não. Desde sempre polissêmico e controverso, é como se o conceito tivesse sido forjado para isso mesmo, com vistas ao aguerrido embate político no qual a desqualificaçáo do adversário, às vezes, interessa mais que pacatas ponderaçóes compreensivas; só num segundo momento, "populismo" teria sido introduzido no mundo mais ameno dos conceitos acadêmicos, sem, porém, despir-se inteiramente da verve polêmica original (FERREIRA, 2001).

\footnotetext{
${ }^{1}$ Professor do Departamento de Filosofia da Universidade de São Paulo (USP), São Paulo, SP - Brasil. (D) https://orcid.org/0000-0002-0610-9993. E-mail: homero@usp.br.
}

https://doi.org/10.1590/0101-3173.2021.v44n4.06.p75

\section{(i)}


É assim que volta e meia ainda topamos com a fórmula "República Populista”, para designar - depreciativamente, of course - os anos entre 1945 e o golpe de 1964 (isso quando não se incluem aí os anos Vargas), numa extrema vulgarização de estudos da melhor cepa acadêmica e que são hoje clássicos das ciências sociais brasileiras, como é o caso dos trabalhos sobre o tema - muito influentes na década de 70 do século passado - de Octavio Ianni (1968) e Francisco Weffort (1978). A força da ideia atua igualmente fora de nossa tradição, e pode orientar um historiador formado no Velho Continente (ZANATTA, 2017), o qual, analisando a América Latina, faz do populismo uma espécie de passe-partout teórico capaz de enquadrar explicativamente boa parte das antigas e sempre atuais mazelas da região. Desde o início, sob o signo do vínculo entre teologia e política, aqui folgadamente se teria cedido à tentação populista que ainda configura um mundo que se debate entre os efeitos da formação deficitária e democracias persistentemente claudicantes.

O sucesso, todavia, nunca eximiu o conceito de críticas. Pelo contrário, sempre houve reação a um enquadramento histórico tendente à visada teleológica e que acaba desconsiderando as particularidades produzidas pelo processo histórico capitalista (afinal, é isso mesmo que está em jogo), em sua miríade de variaçóes locais, especialmente em regióes periféricas: seríamos atavicamente populistas, porque não tivemos classes sociais maduras, faltaram-nos movimentos sociais organizados e o estabelecimento de relaçóes formais claras, e assim por diante; quer dizer, somos populistas, porque não conhecemos uma formação nacional como a europeia. Além disso, a noção de populismo amiúde se acompanha da certeza de que o líder populista é aquele que, espertamente, busca identificar-se ao povo como subterfúgio para comandá-lo e conduzi-lo contra seus próprios interesses; ou seja, o povo figura sempre como o bocó inerme da história. Embora essa seja uma caricatura dos piores usos do conceito de populismo, ajuda ainda assim a entender por que alguns estudiosos acharam por bem abandonar a ideia ou, mais radicalmente, lhe declararem guerra.

Disso provêm, parece-me - e sublinho que o digo à guisa de leitor interessado nessa literatura, mas desarmado de conhecimento especializado -, alguns trabalhos recentes bastante sugestivos: aquele mencionado livro de Ferreira (2001), os volumes da revigorante (ao menos para o entendimento de um leigo) história do Brasil republicano organizada por Ferreira e Delgado (2018), a ampla e instigante análise do "trabalhismo" por Angela de Castro Gomes (2013). Em todos esses casos, a categoria populismo é sistematicamente 
rejeitada à guisa de noção que, produzida desde o alto, reproduz justamente um ponto de vista sobranceiro incapaz de perceber que as classes baixas ou working class (para dizer como E. P. Thompson), os de baixo, em suma, não são apenas joguetes nas mãos de líderes; se, por um lado, são manipulados, por outro, sabem também manipular a manipulação, às vezes inclusive conseguindo instituir coisas novas e conformes aos seus anseios (a legislação trabalhista, por exemplo), numa dialética que, uma vez livre da mácula populista, pode ser mais bem investigada em sua original e decisiva ambiguidade.

Todo esse introito tem por função primeira destacar o mérito do ensaio de Maeso (2021), ao enfiar a mão no vespeiro teórico e, ousadamente, não só convocar dois nomes de primeira grandeza do pensamento político latinoamericano, deslocando assim o conceito de populismo do vácuo semântico do polemismo, como pretender revigorá-lo, por meio das possibilidades trazidas pelo cotejo minucioso desses pensadores. Em meu entendimento, o objetivo final do Autor está, para lá da descoberta de eventuais divergências, na recalibragem conceitual a partir das perspectivas de ambos. Essa operação ocupa as páginas finais do texto e, não por acaso, salienta-se ali a questão geral que gostaria de propor. Sem entrar em maiores detalhes, impossíveis neste espaço, tento esboçá-la a partir de um argumento específico.

Provavelmente, Laclau foi quem mais longe seguiu num esclarecimento teórico do conceito de populismo. Entretanto, para torná-lo o digno nome de uma lógica da política, teve de pagar um custo alto: como lógica geral, o populismo resulta aplicável a tantos casos que sua relevância para o entendimento de situaçóes determinadas diminui significativamente. Noutras palavras, o que se ganha no atacado perde-se no varejo, a tal ponto que não me parece absurdo perguntar se o populismo, tal como entendido por Laclau, ainda teria algo de especificamente conectado ao "Sul" do mundo. Daí ser tão oportuna a tentativa do Autor de introduzir no populismo laclauniano a consideração de aspectos sociais determinados (religião, formação nacional, atividade econômica etc.). É o que ele propóe, por exemplo, relativamente a essa categoria central de Laclau, que é o "significante vazio". Uma vez que "a formação do próprio discurso dificilmente pode ser isolada do tecido social no qual este discurso opera", convém conceber tal significante como "perpassado por elementos constitutivos da sociedade" e lê-lo, "em um prisma chauiniano", como um locus de "projeção dos desejos", "demandas abstratas que" - entretanto, eu intercalaria aqui - "se aglutinam nas palavras de ordem e nas pulsóes políticas". 
Ora, segundo Chaui, esses desejos, essas demandas se enraízam essencialmente numa formação social determinada. No momento em que são introduzidos nas categorias de Laclau, não perdem estas exatamente o que tinham de mais vigoroso, ou melhor, não se tornam incompatíveis com o programa de uma razáo (no sentido forte que parece pretender o argentino e que é inseparável de certa pureza, no sentido em que se fala kantianamente de razão pura) populista? $O$ aspecto universal de uma lógica discursiva que objetiva explicar a produção de todo "sujeito-povo" possível deixa-se atravessar (sem sofrer descaracterização) por "elementos constitutivos" de uma sociedade? E se, alternativamente, esses "elementos" forem concebidos como pertinentes a qualquer sociedade possível, não recaímos na abstração que se buscava contornar?

É desnecessário mais insistir. Minha dúvida geral, que espero tenha ficado mais ou menos clara, concerne basicamente à tensão entre um ponto de vista que pretende o universal para descer ao singular e um ponto de vista que, sem abrir mão do universal, só pode dele aproximar-se, a partir do singular. Resolver essa tensão, creio, é passo primordial para conferir validade e eficácia teórica ao conceito de populismo - se é que vale a pena, claro; coisa de que, admito, não estou inteiramente convencido, pelas dificuldades mesmas apresentadas a título de introito.

\section{REFERÊNCIAS}

FERREIRA, J. (org.). O populismo e sua história: debate e crítica. Rio de Janeiro: Civilização Brasileira, 2001.

FERREIRA, J.; DELGADO, L. A. N. (org.). O Brasil republicano. Rio de Janeiro: Civilização Brasileira, 2018. 5 v.

GOMES, A. de C. A invençáo do trabalhismo. Rio de Janeiro: FGV, 2013.

IANNI, O. O colapso do populismo no Brasil. Rio de Janeiro: Civilização Brasileira, 1968.

MAESO, B. E. A. Em busca do(s) deus(es) ausente(s): o modo de vida populista em Laclau e em Chaui. Trans/form/açắo: revista de filosofia da Unesp, v. 44, n. 4, p. 49-72, 2021.

WEFFORT, F. O populismo na política brasileira. Rio de Janeiro: Paz e Terra, 1978.

ZANATTA, L. Uma breve história da América Latina. São Paulo: Cultrix, 2017; versão eletrônica.

Recebido: $15 / 5 / 2021$

Aceito: $18 / 5 / 2021$ 